\title{
All-Ceramic versus Metal-Ceramic Tooth Supported Single Crowns with a Minimum Follow-up Time of 3 Years; Survival and Complications: A Systematic Literature Review
}

\author{
Ayda Lahiwel ${ }^{1}$ Imen Kalghoum ${ }^{1}$, Belhssan Harzallah ${ }^{2}$, Mounir Cherif $^{1}$ and Dalenda Hadyaoui ${ }^{*}$ \\ ${ }^{1}$ DDM, Department of Fixed Prosthodontics, faculty of dental medicine, Monastir, Tunisia \\ ${ }^{2}$ Professor, Department of Fixed Prosthodontics, Faculty of dental medicine, Monastir, Tunisia
}

\begin{abstract}
Received: December 1, 2017; Accepted: December 20, 2017; Published: January 18, 2018
*Corresponding author: Prof. Dalenda Haduaoui, Department of Fixed Prosthodontics, Research Laboratory of Occlusodontics and Ceramic Prostheses LR16ES15, Faculty of Dental Medicine, University of Monastir, Monastir, Tunisia. Tel: +2165596 7860; E-mail: dalendaresearch@gamil.com / inesazouzi1@gamil.com
\end{abstract}

\begin{abstract}
Purpose: To assess the 3-year survival rates and the incidences of biological and technical complications of all-ceramic and metal-ceramic tooth-supported single crowns.

Material and methods: An online research of literature on Pubmed was conducted independently by 3 reviewers to identify the clinical studies performed from 2000 up to 2017 and completed by a manual research. Keywords, inclusion and exclusion criteria were well-defined.

Results: The research revealed 501 titles and led to a final analysis of 31 full text articles. Only 6 studies met the inclusion criteria and reported on 215 metal-ceramic and 501 all-ceramic TSSCs. The meta-analysis of the included studies indicated an estimated survival rate of metal-ceramic TSSCs of $90.14 \%$ (95\% CI: 89.72\%-91.35\%) after 3 years. This was a little bit higher than the estimated 3-year survival rate of Lithium-disilicate (89.54\%; 95\% CI: 87.18\%-91.89\%). However the 3-year survival rate, of Zirconia TSSCs was statistically much higher (92.01\%; 95\% CI: 89.58-94.43\%). When the outcomes in anterior and posterior regions were compared, Zirconia and Lithium-disilicate TSSCs exhibited survival rates of $91.64 \%$ and 91.12\% respectively, in the posterior region, where metal-ceramic TSSCs exhibited only $90.14 \%$ as a 3-year survival rate. As for the anterior region, we could only compare the TSSCs made out of Lithium-disilicate and Zirconia as the metal-ceramic ones were all laid on the posterior regions. Zirconia performed the highest 3-year survival rate in the anterior region (93.54\%; 95\% CI: 91.08-96\%) whereas Lithium-disilicate showed only $87.5 \%$. This was due to the low level of the mechanical properties of such material, which clinically indicated by major chipping and tooth fracture.

Conclusion: Survival rates of metal-ceramic crowns were nearly similar to those reported for most types of all-ceramic TSSCs in the posterior region. Weaker Lithium-disilicate-based ceramics should be limited to application in the anterior region, even if they expressed a higher survival rate in the anterior regions. Zirconia-based TSSCs should not be considered as a primary option due to their high incidence of technical problems.
\end{abstract}

Keywords: Tooth-supported single crowns; Fixed dental prosthesis; All-ceramic; Metal-ceramic; Survival; Technical complications; Biological complications;

\section{Introduction}

Nowadays; all ceramic prostheses are considered as an established alternative compared to metal-ceramics. They offered more favorable esthetics by miming so naturally the optical properties of teeth [1]. Another more recent factor influencing the choice of ceramic materials is the pronounced cost for high precious metals as gold. The main defect of the firstly introduced ceramics as the feldspathic ones was the mechanical stability that limited the indication for all ceramic restorations to anterior regions and to single units fixed dental-prostheses.

In the last years, many new dental ceramic materials were developed in order to increase the mechanical stability of the allceramic restorations and still maintaining the esthetic benefit.
Among those materials; leucite/lithium-disilicate glass ceramics and oxide ceramics such as alumina and Zirconia that appeared to be very promising for different indications [2,3].

Reconstructions made of these more recently developed ceramics were placed at posterior sites and even included multiple-unit fixed dental-prostheses. Our systematic review focused on tooth-supported single crowns, as the published studies reporting on this type of FDPs, were so limited and our objective was to obtain an estimate of the long term success, survival and complication rates of all-ceramic single crowns versus the metal-ceramic ones over an observation period of at least 3 years and to compare the biological and technical complication rates of all-ceramic TSSCs with the ones made out of metal-ceramic. 


\section{Material and Methods}

An electronic literature search was carried out from the data banks MEDLINE, using the database PubMed. The indexing language based on keywords has been used according to the formula 'PICO'. The keywords were used after being audited if they were MeSH ones.

The formula PICO: Population, Intervention, Comparison and Outcomes, the "PICO" for this systematic review was defined as follows:

Population: Anterior and/or posterior tooth-supported single crowns.

Intervention: All-ceramic tooth-supported single crowns.

Comparison: Metal-ceramic tooth-supported single crowns.

Outcomes: Clinical survival rates, and technical and/or biological complication rates.

The search was limited to human studies in dental journals written in English language. Articles published from 2000 up to 2017 and including the inclusion criteria.

The following detailed search terms were used and the search strategy was follows:

P and I: crowns [MeSH] OR crown [MeSH] OR dental crowns [MeSH] OR crowns, dental [MeSH] OR Denture, Partial, Fixed [Mesh])) OR (crown*[all fields] OR fixed partial denture*[all fields] OR FPD[all fields] OR FPDs [all fields] OR fixed-dental prosthesis [all fields] OR fixed dental prostheses [allfields] OR FDP [all fields] OR FDPs [all fields] OR bridge*[all fields].

C: Ceramic [MeSH] OR ceramics [MeSH] OR metal-ceramic restorations [MeSH])) OR (ceramic*[All Fields] ORall-ceramic [all fields] OR Dental Porcelain [All Fields] OR metal-ceramic [All Fields].

O: Survival [Mesh] OR survival rate [Mesh] OR survival analysis [Mesh] OR dental restoration failure [Mesh] OR prosthesis failure [Mesh] OR treatment failure [Mesh].The combination in the builder was set as "P \& I AND C AND O".

Titles and abstracts of the searches were independently screened by two reviewers for possible inclusion in the review. Furthermore, the full text of all studies of possible relevance was then obtained and spilt into literature on single crowns. The literature on single crowns was independently assessed by three of the reviewers. Any disagreement regarding the assortment articles was resolved by discussion.

\section{Inclusion criteria}

- The additional inclusion criteria for study selection were:

- Studies with a minimum mean follow-up period of 3 years.

- Prospective studies.

- Randomized Controlled Trial.
- Cohorts.

- Studies between 2000 and 2017

- Studies reported details on the characteristics of the reconstructions, on materials and methods, on the biological complications and their appearance and on the results.

- Studies had to include and follow-up at least 10 patients.

- Patients of studies had been examined clinically at regular intervals.

- Studies on tooth-supported single crowns, fixed units with metal and ceramic frameworks were considered.

- Data on the survival and failure of TSSCs and descriptions of the biological and technical complications had to be reported.

Exclusion criteria

The following study types were excluded:

- In vitro or animal studies.

- Studies with a mean follow-up time less than 3 years.

- Clinical or case reports.

- Narrative review.

- Retrospectives studies.

- Fixed implant prosthesis.

- Partial removable dentures.

- Plural fixed dental prosthesis (PFDPs).

\section{Data extraction}

Data on the following parameters were extracted: Author(s), Title, Journal, Year of publication, Study design (cohort, metaanalysis, randomized controlled clinical trials, prospective case series, prospective study, and prospective clinical study), Population (Planned number of patients, Sex, Age), number of patients at the end of the study, Drop-out rate, Mean age, Operators (practitioners), Material framework, Brand name of framework material, Veneering material, Brand name of veneering material, Type of manufacturing procedure, Number of single crowns, Location of single crowns (anterior, posterior, maxilla, mandible), Reported mean follow-up time, Published single crowns survival rate, Number of single crowns lost (total, anterior, posterior), Reported biological complications (caries, periodontal and endodontic diseases, root fracture, tooth fracture, marginal discrepancy), Reported technical complications (framework fracture, minor chipping, major chipping, loss of retention), Reported number of TSSCs free of complications, Specificity of the study, Aesthetic properties, Biological properties.

\section{Statistical analysis}

Survival was defined as the tooth-supported single crowns remaining in situ with or without modification during the observation period. Failures included every type of complication 
that lead to the removal or the replacement of the restoration or the loss of the tooth. Complication may led or not to a failure.

Failure and complication rates were calculated by dividing the number of events (failure or complication) in the numerator by the total tooth-supported single crown exposure time in the denominator.

The numerator could usually be extracted directly from the publication. The total exposure time was calculated by talking the sum of:

(1) Exposure time of tooth-supported single crowns that could be followed for the whole observation time.

(2) Exposure time up to a failure of the tooth-supported single crown that were lost due to failure during the observation time.

(3) Exposure time up to the end of observation time for toothsupported single crowns that did not complete the observation period due to reasons such as death, change of address, refusal to participate, non-response, chronic illnesses, missed appointments and work commitments.

For each study, event rates for the tooth-supported single crowns were calculated by dividing the total number of events by the total tooth-supported single crown exposure time in years. The total exposure was determined by multiplying the total number of tooth-supported single crowns by the mean follow-up time, no more precise information. For further analysis, the total number of events was considered to be Poisson, disturbed for a given sum of tooth-supported single crown exposure years and Poisson regression with a logarithmic link-function with a total exposure time per study as an offset were used [4].

Robust standard errors were calculated to obtain 95\% confidence intervals of the summary estimates for the event rates $[4,5]$. To assess heterogeneity of the study specific event rates, the Spearman goodness-of-fit statistics and associated $\mathrm{p}$-value were calculated. If the goodness-of-fit $\mathrm{p}$-value was below 0.05 three year survival; proportions had been calculated via the relationship between event rate and survival function $S, S$ $(\mathrm{T})=\exp \left(-\mathrm{T}^{*}\right.$ event rate), by assuming constant event rates [5]. The 95\% confidence intervals for the survival proportions were calculated by using the $95 \%$ confidence limits of the event rates. Multivariable Poisson regression was used to formally compare construction subtypes and to assess other study characteristics. All analyses were performed using Stata ${ }^{\circledR}$, version 13.1 .

\section{Results}

The research on MEDLINE using the Boolean-equation had identified 501 articles. During the preselecting step, 437 articles were excluded based on titles and the year of publication. After reading, other 33 articles were excluded based on the exclusion criteria adopted in the study. Among the 31 selected articles, only 3 corresponded to studies on tooth-supported single crowns. 3 more articles were added based on manual research (Figure 1) (Table 1).

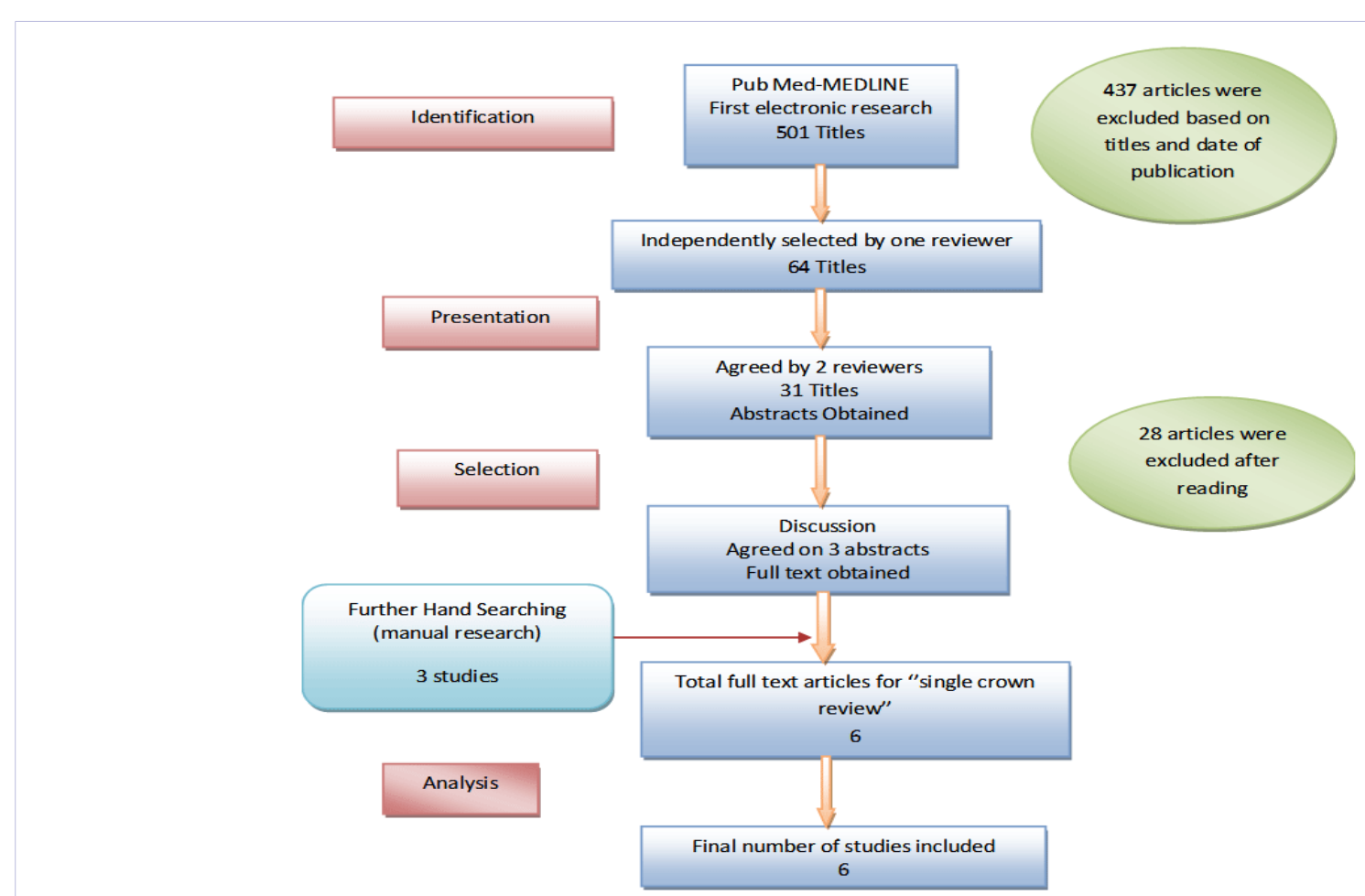

Figure 1: Research strategy and included studies on TSSCs 
Table 1: Study and patient characteristics of the reviewed studies of tooth-supported single crowns

\begin{tabular}{|c|c|c|c|c|c|c|c|c|c|}
\hline $\begin{array}{c}\text { Authors } \\
\text { Year }\end{array}$ & $\begin{array}{l}\text { Study } \\
\text { design }\end{array}$ & $\begin{array}{c}\text { Planned } \\
\text { Number } \\
\text { of } \\
\text { Patients }\end{array}$ & $\begin{array}{c}\text { Drop-Out } \\
\text { Rate }\end{array}$ & Mean Age & $\begin{array}{l}\text { Number } \\
\text { of tooth } \\
\text { supported } \\
\text { single- } \\
\text { crowns }\end{array}$ & Practitioners & Operators & $\begin{array}{l}\text { Reported } \\
\text { mean } \\
\text { follow-up }\end{array}$ & $\begin{array}{c}\text { Follow-up } \\
\text { Rage }\end{array}$ \\
\hline $\begin{array}{l}\text { Edelhoffd D } \\
\text { et al., } 2017 \\
\text { (6) }\end{array}$ & $\begin{array}{l}\text { Prospective } \\
\text { clinical } \\
\text { study }\end{array}$ & 45 & $17,77 \%$ & $32,9+/-8,9$ & 106 & $\begin{array}{c}9 \text { trained and } \\
\text { calibrated } \\
\text { clinicians }\end{array}$ & $\begin{array}{l}\text { One } \\
\text { principal } \\
\text { investigator } \\
\text { for the } \\
\text { follow-up }\end{array}$ & $11,4+/-3,8$ & 6 months \\
\hline $\begin{array}{l}\text { Gianluca M. } \\
\text { et al., } 2015 \\
\text { (7) }\end{array}$ & $\begin{array}{l}\text { Prospective } \\
\text { clinical } \\
\text { study }\end{array}$ & 138 & $36,23 \%$ & $59+/-1$ & 202 & $\begin{array}{l}\text { One private } \\
\text { practitioner for } \\
\text { the prosthetic } \\
\text { procedures }\end{array}$ & $\begin{array}{c}\text { An } \\
\text { independent } \\
\text { operator } \\
\text { that had } \\
\text { not been } \\
\text { involved in } \\
\text { the original } \\
\text { prosthetic } \\
\text { procedures }\end{array}$ & 7 years & 6 months \\
\hline $\begin{array}{l}\text { Hansel } \mathrm{K} . \\
\text { et al., } 2013 \\
\text { (8) }\end{array}$ & $\begin{array}{l}\text { Prospective } \\
\text { clinical } \\
\text { study }\end{array}$ & 95 & $22,6 \%$ & 43,75 & 190 & $\begin{array}{l}10 \text { private } \\
\text { practitioners } \\
\text { (general } \\
\text { dentist) }\end{array}$ & $\begin{array}{c}\text { An } \\
\text { independent } \\
\text { operator }\end{array}$ & 10 years & 6 months \\
\hline $\begin{array}{c}\text { Gersdorff } N . \\
\text { et al., } 2013 \\
\text { (10) }\end{array}$ & $\begin{array}{l}\text { Randomized } \\
\text { controlled } \\
\text { trial }\end{array}$ & 53 & $7,54 \%$ & $49,6+/-9,9$ & 150 & $\begin{array}{c}\text { An experience } \\
\text { clinician (S.R) } \\
\text { in private } \\
\text { practice in } \\
\text { Germany }\end{array}$ & $\begin{array}{c}\mathrm{An} \\
\text { independent } \\
\text { operator }\end{array}$ & $\begin{array}{c}3 \text { years }+/- \\
6 \text { months }\end{array}$ & 6 months \\
\hline $\begin{array}{l}\text { Mutinelli } S . \\
\text { et al., } 2012 \\
\text { (9) }\end{array}$ & $\begin{array}{l}\text { Prospective } \\
\text { clinical } \\
\text { study }\end{array}$ & 60 & $3,33 \%$ & 32 & 60 & $\begin{array}{c}\text { A } \\
\text { prosthodontist } \\
\text { An experienced } \\
\text { dental } \\
\text { technician }\end{array}$ & $\begin{array}{c}\text { An } \\
\text { independent } \\
\text { operator }\end{array}$ & 5 years & 6 months \\
\hline $\begin{array}{c}\text { Sforza C. } \\
\text { et al., } 2011 \\
(11)\end{array}$ & $\begin{array}{l}\text { Prospective } \\
\text { case series }\end{array}$ & 138 & $21,74 \%$ & 49,2 & 202 & $\begin{array}{l}\text { General private } \\
\text { patricians in } \\
\text { Italy }\end{array}$ & $\begin{array}{c}2 \\
\text { Independent } \\
\text { evaluators } \\
\text { (GMT, ES) } \\
\text { for the study }\end{array}$ & 3 years & 6 months \\
\hline
\end{tabular}

Among the 6 selected articles, 4 corresponded to Prospective clinical studies one to a Randomized controlled trial and another one to a Prospective case series, evaluating 3 to 15 years followup of the single restorations with all ceramic and metal ceramic materials [6-11]. The articles included in this systematic review are listed in table 1 by author, study design and patient characteristics. The 6 clinical studies included one 15-years follow-up, one 10-years follow-up, one 7-years follow-up, one 5-years follow-up and two 3-years follow-up [6-11]. The studies included patients between the age of 32 and 60 with a follow-up rage of 6 months. The proportions of patients, who could not be followed for complete studies periods or at least 3 years, were calculated for all studies as a Drop-out rate and ranged from 3.33 $\%$ to $36.23 \%$.

According to material and manufacturing procedures, two studies compared all-ceramic crowns made out of zirconia (one study on CAD/CAM System; cercon smart ceramics+) the remaining on Procera and Lava systems, to metal ceramic crowns $[9,10]$. Furthermore, one study was reporting on metal-ceramic tooth-supported single crowns, one on crowns made out of Lithium with IPS e-max press and two on crowns made out of Zirconia with the CAD/CAM technology $[6-8,11]$. 
For metal-ceramic TSSCs only noble metal or high noble metal alloys were used for the framework; based on the conventional lost wax technique and the veneering was based on the manual layering technique with a standard firing process, using ; feldspathic ceramic, low fused porcelain and non-specific porcelain [8-10]. For all-ceramic TSSCs the layering material used during the various studies was as follows: fluorapatite veneering ceramic, feldspathic porcelain and layering ceramic $[9,10]$. The veneering technique was based on manual layering, the slow cooling protocol and various CAD/CAM manufacturing procedures such as Procera system and 3M ESPE [6, 7, 9-11] (Figure 2) (Table 2).

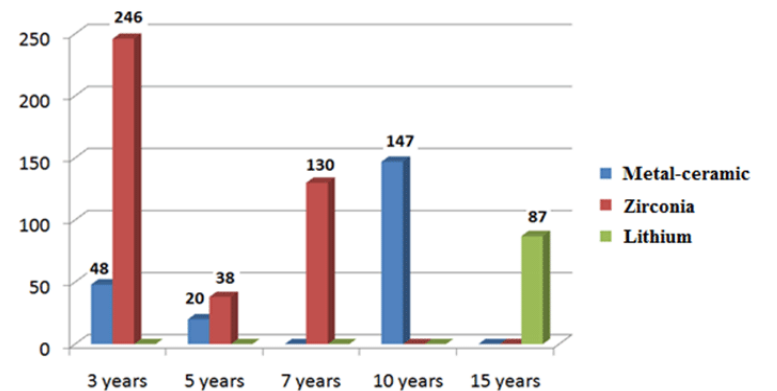

Figure 2: Tooth-supported single-crown's mean follow-up time according to material

\begin{tabular}{|c|c|c|c|c|c|c|c|c|}
\hline $\begin{array}{c}\text { Author } \\
\text { Year }\end{array}$ & $\begin{array}{l}\text { Number of single- } \\
\text { supported-dental } \\
\text { crowns during the } \\
\text { study }\end{array}$ & $\begin{array}{c}\text { Metal-ceramic } \\
\text { crowns }\end{array}$ & $\begin{array}{c}\text { All-ceramic } \\
\text { crowns }\end{array}$ & $\begin{array}{l}\text { Material } \\
\text { framework }\end{array}$ & $\begin{array}{c}\text { Brand } \\
\text { name of } \\
\text { framework } \\
\text { material }\end{array}$ & $\begin{array}{l}\text { Veneering } \\
\text { material }\end{array}$ & $\begin{array}{c}\text { Brand } \\
\text { name of } \\
\text { veneering } \\
\text { material }\end{array}$ & $\begin{array}{c}\text { Type of } \\
\text { manufacturing } \\
\text { procedure }\end{array}$ \\
\hline $\begin{array}{l}\text { Edelhoffd } \\
\text { D et al., } \\
2017 \text { (6) }\end{array}$ & 87 & 0 & 87 & $\begin{array}{c}\text { Lithium } \\
\text { disilicate } \\
\text { glass cermaic }\end{array}$ & $\begin{array}{l}\text { IPS e-max } \\
\text { Press } \\
\text { (Ivoclar } \\
\text { Vivadent) }\end{array}$ & $\begin{array}{c}\text { Fluorapatite } \\
\text { veneering } \\
\text { ceramic }\end{array}$ & $\begin{array}{l}\text { IPS Eris for } \\
\text { E2 Ivoclar } \\
\text { Vivadent }\end{array}$ & $\begin{array}{c}\text { Framework: } \\
\text { IPS e-max press } \\
\text { Veneering : layering } \\
\text { technique }\end{array}$ \\
\hline $\begin{array}{l}\text { Gianluca } \\
\text { M. et al., } \\
2015 \text { (7) }\end{array}$ & 130 & 0 & 130 & Zirconia & $\begin{array}{c}\text { Zirite, } \\
\text { Keramo, } \\
\text { Tavemerio, } \\
\text { Como, Italia }\end{array}$ & $\begin{array}{c}\text { Feldspathic } \\
\text { porcelain }\end{array}$ & $\begin{array}{c}\text { CZR } \\
\text { Noritake } \\
\text { Kizai Co, } \\
\text { Ldt, Nagoya, } \\
\text { Japan }\end{array}$ & $\begin{array}{l}\text { Framework : CAD/ } \\
\text { CAM ; computer- } \\
\text { aided design/ } \\
\text { computer assisted } \\
\text { manufacturing } \\
\text { Veneering : slow } \\
\text { cooling protocol }\end{array}$ \\
\hline $\begin{array}{l}\text { Hansel K. } \\
\text { et al., } 2013 \\
\text { (8) }\end{array}$ & 147 & 147 & 0 & $\begin{array}{l}\text { Four noble } \\
\text { metal alloys }\end{array}$ & $\begin{array}{c}\text { Degussa } \\
\text { GmbH ; } \\
\text { Hanau, } \\
\text { Germany } \\
\text { Degudent } \\
\text { BIOcclus } \\
\text { Deva } \\
\text { Degupal }\end{array}$ & $\begin{array}{c}\text { Feldspathic } \\
\text { ceramic }\end{array}$ & $\begin{array}{c}\text { Duceram; } \\
\text { Degu-Dent } \\
\text { GmbH, } \\
\text { Hanau, } \\
\text { Germany }\end{array}$ & $\begin{array}{l}\text { Conventional (the lost } \\
\text { wax technique) } \\
\text { Veneering : } \\
\text { Standard firing } \\
\text { protocol }\end{array}$ \\
\hline $\begin{array}{l}\text { Gersdorff } \\
\text { N. et al., } \\
2013(10)\end{array}$ & 100 & 48 & 52 & $\begin{array}{l}\text { High noble } \\
\text { alloy }\end{array}$ & $\begin{array}{c}\text { Degunorm+ } \\
+ \\
\\
\text { Cerona } \\
\text { Smart } \\
\text { Ceramics }+\end{array}$ & $\begin{array}{l}\text { Low-fused } \\
\text { porcelain }\end{array}$ & $\begin{array}{c}\text { Duceragold } \\
\text { Kiss }^{+} \\
\\
\\
\text {Cercon } \\
\text { Ceram-Kiss }{ }^{+}\end{array}$ & $\begin{array}{c}\text { Metal-framework: } \\
\text { Conventional (the lost } \\
\text { wax technique) } \\
\text { Veneering: } \\
\text { Standard firing } \\
\text { protocol } \\
\text { Zirconia-framework: } \\
\text { CAD/CAM System } \\
\text { (cercon smart } \\
\text { ceramics+) } \\
\text { Veneering: } \\
\text { Manual layering } \\
\text { technique with a } \\
\text { firing process }\end{array}$ \\
\hline
\end{tabular}




\begin{tabular}{|c|c|c|c|c|c|c|c|c|}
\hline $\begin{array}{c}\text { Mutinelli } S . \\
\text { et al., } 2012 \\
\text { (9) }\end{array}$ & 58 & 19 & $\begin{array}{c}39 \\
\text { Group P : } 19 \\
\text { Group L : } 20\end{array}$ & $\begin{array}{l}\text { Noble alloys } \\
\text { Zirconium- } \\
\text { oxide } \\
\text { copings }\end{array}$ & $\begin{array}{l}\text { Valcambi, } \\
\text { Balerna, } \\
\text { Switizerland } \\
\\
\text { Group } \\
\text { P : Noble } \\
\text { Biocare, } \\
\text { Gôteborg, } \\
\text { Sweden } \\
\\
\text { Group } \\
\text { L : Noble } \\
\text { Biocare }\end{array}$ & $\begin{array}{l}\text { Porcelain } \\
\text { Group P : } \\
\text { Layering } \\
\text { ceramic } \\
\text { Group L : } \\
\text { Layering } \\
\text { ceramic }\end{array}$ & $\begin{array}{c}\text { Noritake } \\
\text { EX-3; } \\
\text { Noritake, } \\
\text { Nagoya, } \\
\text { Japan } \\
\\
\text { Group P : } \\
\text { NobelRondo } \\
\text { Zirconia } \\
\text { (Nobel } \\
\text { Biocare) } \\
\\
\text { Group L : } \\
\text { Lava Ceram } \\
\text { (3M ESPE) }\end{array}$ & $\begin{array}{l}\text { Metal-framework: } \\
\text { Conventional (the lost } \\
\text { wax technique) } \\
\text { Veneering : } \\
\text { Manual layering } \\
\text { technique with a } \\
\text { firing proces } \\
\text { Zirconium } \\
\text { framework : } \\
\text { Group P : CAD/CAM } \\
\text { technology with } \\
\text { Procera system } \\
\text { Group L : } \\
\text { CAD/CAM technology } \\
\text { with 3M ESPE } \\
\text { Veneering : } \\
\text { Group P : Procera } \\
\text { system } \\
\text { Group L : } \\
\text { 3M ESPE }\end{array}$ \\
\hline $\begin{array}{c}\text { Sforza C. } \\
\text { et al., } 2011 \\
\text { (11) }\end{array}$ & 194 & 0 & 194 & $\begin{array}{l}\text { Zirconia- } \\
\text { oxide }\end{array}$ & $\begin{array}{c}\text { Zirite, } \\
\text { Keramo, } \\
\text { Tavernerio, } \\
\text { Como, Italia }\end{array}$ & $\begin{array}{c}\text { Feldspathic } \\
\text { ceramic }\end{array}$ & $\begin{array}{c}\text { CZR } \\
\text { Noritake } \\
\text { Kizai Co. } \\
\text { Ldt, Nagoya, } \\
\text { Japan }\end{array}$ & $\begin{array}{c}\text { Zirconium } \\
\text { Framework: } \\
\text { CAD/CAM technology } \\
\text { Veneering : } \\
\text { Manual layering } \\
\text { technique by a master } \\
\text { ceramist (SST Dental } \\
\text { Lab, Segrate, Italy) }\end{array}$ \\
\hline
\end{tabular}

In all included studies, preparation guidelines according to the manufacturer's recommendation were considered. Different measurement methods were used to exanimate the TSSCs at the recall appointments; in order to identify the technical and biological complications. In two studies remarkable complications of TSSCs were discovered and the criteria used were not specified $[7,8]$. For biological and technical complications the California Dental Association criteria (CDA) was used in one study, in the company of periodontal parameters such as plaque index, gingival index ... $[6,14]$.

The technical complications were evaluated according to Heintz/Rousson 2010 chipping criteria in two studies $[6,10]$. The United States Public Health Service (USPHS) criteria were used to evaluate technical issues in one study [9]. Technical and biological complications were defined based on a specific clinical evaluation according to Hickel et al. in one study [11]. The estimated survival rates of 716 TSSCs ranged from $80 \%$ to $93.54 \%$ which were predominantly posterior single reconstructions.

\section{Crown survival}

Overall, in the 3 studies reporting on MC TSSCs with a mean follow-up of 7 years +/- 6 months. An estimated annual failure rate of 0.051 was reported, translated into an estimated 3-year survival of metal-ceramic crowns of $90.14 \%$ [8-10]. In comparison, all ceramic crowns had an annual failure rate ranging between 0.015 and 0.15 , translating into overall estimated 3-year survival rates ranging between $80 \%$ and $93.54 \%$. This was based on 5 studies on all-ceramic crowns included in this analysis [6-11]. The survival rates of all-ceramic crowns differed for the various types of ceramics. One study reported on Lithium glass ceramic and rendered an estimated 3-year survival rate of $89.54 \%$ [6]. This survival rate was a little bit lower than the one reported for the gold standard, metal-ceramic crowns. Tooth-supported single crowns made out of zirconia had a significantly higher estimated 3 -year survival rate compared to metal-ceramic crowns. The zirconia-based crowns reached an estimated 3-year survival rate of $92.01 \%$ (Table 3).

\section{Anterior vs. posterior regions}

TSSCs were distributed as 103 crown in anterior regions and 603 crown in posterior regions. The distribution of TSSCs according to material was as follows: none of MC TSSCs; 38 crowns were made of lithium and 65 of zirconia [6, 7, 9-11]. For the posterior regions we have, 215 metal-ceramic single crowns and 388 all-ceramic crowns, in which 49 crown were made out from Lithium and 339 from zirconia-oxide and zirconium [6-11]. When outcomes of anterior and posterior tooth-supported single crowns were compared no statistically significant differences of the survival rates were found for metal-ceramic crowns, as they were all made on posterior regions for the 3 studies analyzed. For the entire $215 \mathrm{MC}$ TSSCs posed in the posterior region, we had an estimated failure rate of 0.015 . 
All-Ceramic versus Metal-Ceramic Tooth Supported Single Crowns with a Minimum Follow-up Time of 3 Years; Survival and Complications: A Systematic

Table 3: Annual failure and survival rates of single crowns (estimated evaluation after 3 years)

\begin{tabular}{|c|c|c|c|c|c|c|}
\hline Study & $\begin{array}{c}\text { Total no. of } \\
\text { crowns after } \\
\text { drop-out }\end{array}$ & $\begin{array}{l}\text { Mean follow-up } \\
\text { time }\end{array}$ & $\begin{array}{l}\text { No. of failures } \\
\text { (after } 3 \text { years) }\end{array}$ & $\begin{array}{c}\text { Total exposure } \\
\text { time (after } 3 \\
\text { years) }\end{array}$ & $\begin{array}{l}\text { Estimated annual } \\
\text { failure rate (per } \\
100 \text { crown years) }\end{array}$ & $\begin{array}{c}\text { Estimated survival } \\
\text { after } 3 \text { years (95\% } \\
\text { CI) }\end{array}$ \\
\hline Metal ceramic: & & & & & & \\
\hline $\begin{array}{l}\text { Hansel K. et al., } 2013 \\
\text { (8) }\end{array}$ & 147 & 10 years & 8 & 441 & 0.054 & $89.83 \%$ \\
\hline $\begin{array}{l}\text { Gersdorff N. et al., } \\
2013(10)\end{array}$ & 48 & $\begin{array}{c}3 \text { years }+/-6 \\
\text { months }\end{array}$ & 2 & 144 & 0.041 & $91.04 \%$ \\
\hline $\begin{array}{l}\text { Mutinelli S. et al., } \\
2012 \text { (9) }\end{array}$ & 20 & $\begin{array}{c}5 \text { years }+/-6 \\
\text { months }\end{array}$ & 1 & 60 & 0.05 & $90.25 \%$ \\
\hline $\begin{array}{l}\text { Total } \\
\text { Summary estimated } \\
(95 \% C I)\end{array}$ & 215 & $\begin{array}{c}\text { 7years }+/-6 \\
\text { months }\end{array}$ & 11 & 645 & $0.051(0.049-0.052)$ & $\begin{array}{c}90.14 \%(89.72- \\
91.35 \%)\end{array}$ \\
\hline $\begin{array}{l}\text { Leucit glass } \\
\text { ceramics: }\end{array}$ & & & & & & \\
\hline $\begin{array}{l}\text { Edelhoffd D et al., } \\
2017 \text { (6) }\end{array}$ & 87 & $\begin{array}{c}11.4+/-3.8 \\
\text { years }\end{array}$ & 5 & 261 & $0.057(0.052-0.062)$ & $\begin{array}{c}89.54 \%(87.18 \%- \\
91.89 \%)\end{array}$ \\
\hline $\begin{array}{l}\text { Zirconia Oxide/ } \\
\text { Zirconium: } \\
\text { Gianluca M. et al., } \\
2015 \text { (7) }\end{array}$ & 130 & 7 years & 2 & 390 & 0.015 & $93.54 \%$ \\
\hline $\begin{array}{l}\text { Gersdorff N. et al., } \\
2013(10)\end{array}$ & 52 & $\begin{array}{c}3 \text { years }+/-6 \\
\text { months }\end{array}$ & 2 & 156 & 0.038 & $91.34 \%$ \\
\hline $\begin{array}{l}\text { Mutinelli S. et al., } \\
2012(9)\end{array}$ & 38 & 5 years & 6 & 114 & 0.15 & $80 \%$ \\
\hline $\begin{array}{l}\text { Sforza C. et al., } 2011 \\
\text { (11) }\end{array}$ & 194 & 3 years & 3 & 582 & 0.015 & $93.53 \%$ \\
\hline $\begin{array}{l}\text { Total } \\
\text { Summary estimated } \\
(95 \% C I)\end{array}$ & 414 & $\begin{array}{c}4 \text { years }+/-6 \\
\text { months }\end{array}$ & 13 & 1656 & $0.031(0.022-0.04)$ & $\begin{array}{c}92.01 \%(89.58- \\
94.43 \%)\end{array}$ \\
\hline All ceramic crowns & 501 & $\begin{array}{c}6 \text { years }+/-3 \\
\text { months }\end{array}$ & 18 & 3006 & $0.036(0.03-0.042)$ & $91.58 \%(89.16-94 \%)$ \\
\hline
\end{tabular}


For the crowns made out of Lithium, there was a significant difference of survival rates between anterior region, which exhibited an estimated 3-years survival rate of $87.5 \%$ and the posterior region with an estimated 3-year survival rate of 91.12\%. 38 crowns made out of Lithium and posed in anterior region, showed a higher estimated annual failure rate of 0.079 compared to the 49 crowns posed in posterior region, which showed a failure rate of 0.04. Crowns made out of Zirconia, showed significantly lower survival rates in the posterior region than the anterior ( $93.54 \%$ vs. $91.64 \%$ ). 65 crowns were posed in the anterior region with a failure rate of 0.015 , which was lower compared with the 339 crowns posed in the posterior region and showed a failure rate of 0.035 .

For all-ceramic crowns there is no significant difference of survival rates between anterior and posterior regions (91.31\% vs. 91.57\%). For the total number of TSSCs, there was no statistically difference between the anterior and the posterior regions, which

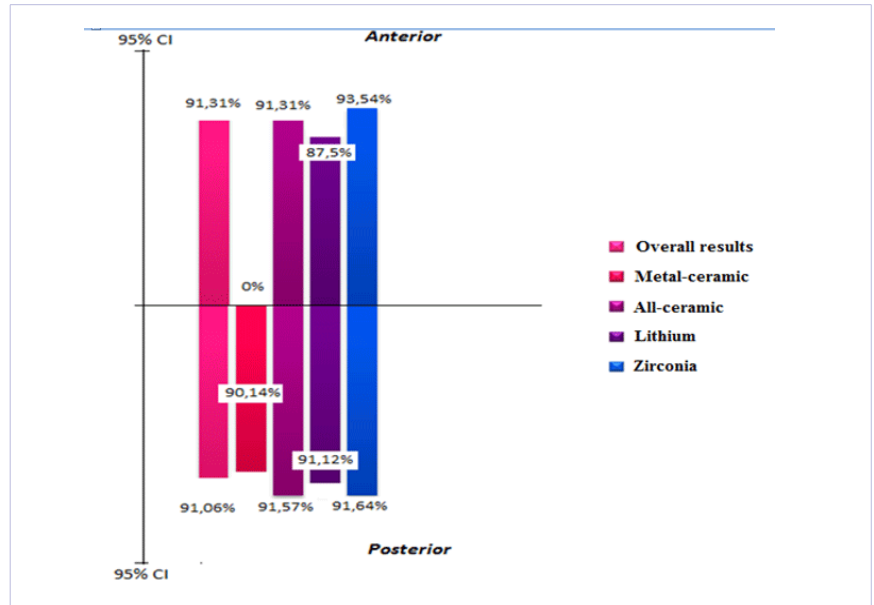

Figure 3: Survival rates by 3 years; Anterior versus Posterior regions according to materials

\begin{tabular}{|c|c|c|c|c|c|c|}
\hline Type of crowns & $\begin{array}{c}\text { Total number of } \\
\text { crowns }\end{array}$ & $\begin{array}{c}\text { Estimated annual } \\
\text { failure rate }\end{array}$ & $\begin{array}{c}3 \text { year survival } \\
\text { summary } \\
\text { estimate }(95 \% \\
\text { CI) }\end{array}$ & $\begin{array}{c}\text { Total number } \\
\text { of crowns }\end{array}$ & $\begin{array}{c}\text { Estimated annual } \\
\text { failure rate }\end{array}$ & $\begin{array}{c}3 \text { year survival } \\
\text { summary estimate } \\
(95 \% \mathrm{CI})\end{array}$ \\
\hline Regions & \multicolumn{3}{|c|}{ Anterior } & \multicolumn{3}{|c|}{ Posterior } \\
\hline Overall results & 103 & $0.04(0.036-0.043)$ & $\begin{array}{c}\text { 91.31\% (88.91- } \\
\text { 93.71\%) }\end{array}$ & 603 & $0.04(0.036-0.044)$ & $\begin{array}{c}91.06 \% \text { (88.67- } \\
93.45 \%)\end{array}$ \\
\hline $\begin{array}{c}\text { Metal ceramic } \\
(8,9,10)\end{array}$ & 0 & 0 & 0 & 215 & $\begin{array}{c}0.051(0.047- \\
0.064)\end{array}$ & $\begin{array}{c}90.14 \%(89.72- \\
91.35 \%)\end{array}$ \\
\hline $\begin{array}{c}\text { All-ceramic }(6,7, \\
9,10,11)\end{array}$ & 103 & $0.04(0.036-0.044)$ & $\begin{array}{c}91.31 \%(88.91- \\
93.71 \%)\end{array}$ & 388 & $0.036(0.03-0.042)$ & $\begin{array}{c}91.57 \% \text { (89.17- } \\
93.97 \%)\end{array}$ \\
\hline $\begin{array}{l}\text { Leucit glass } \\
\text { ceramics (6) }\end{array}$ & 38 & $0.079(0.062-0.095)$ & $\begin{array}{c}87.5 \%(85.2- \\
89.8 \%)\end{array}$ & 49 & $0.04(0.036-0.043)$ & $\begin{array}{c}91.12 \%(88.73- \\
93.51 \%)\end{array}$ \\
\hline $\begin{array}{l}\text { Zirconia Oxide/ } \\
\text { Zirconium }(7,9, \\
10,11)\end{array}$ & 65 & $0.015(0.002-0.032)$ & $\begin{array}{c}93.54 \%(91.08- \\
96 \%)\end{array}$ & 339 & $\begin{array}{c}0.035(0.028- \\
0.041)\end{array}$ & $\begin{array}{c}91.64 \%(89.22- \\
94.05 \%)\end{array}$ \\
\hline
\end{tabular}

exhibited 3-year survival rates of $91.31 \%$ VS $91.06 \%$ respectively. Over all, in the anterior region, the crowns made out of Lithium showed a lower 3-years estimated survival rate compared to SCs made out of Zirconia (87.5\% VS 93.54\%). Whereas in the posterior region the several types of SCs could be compared and showed a statistically difference between the MC SCs and those made out of Lithium and Zirconia, with $90.14 \%$ VS $91.13 \%$ and $91.64 \%$ as a 3-years estimated survival rates, respectively.

Finally to summarize, we could compared all-ceramic and the metal-ceramic SCs only in the posterior region, as none of the metal-ceramic crowns were placed on the anterior. A 3-year estimated survival rate was calculated as an over-all result for both MC SCs and CC SCs and showed a statistically difference between both of them (90.14\% VS 91.57\%) (Table 4) (Figure 3).

\section{Technical and biological complications}

Table 5 and 6 display an overview of the incidences, the estimated annual complication rates and the cumulative 3-years complication rates of technical and biological complications for metal-ceramic and the two types of all-ceramic TSSCs, as well as the statistical differences between the crown types. 
Table 5: Overview of technical complications for different types of SCs.

\begin{tabular}{|c|c|c|c|c|c|c|c|c|c|}
\hline \multirow[t]{2}{*}{ Complication } & $\begin{array}{c}\text { Number } \\
\text { of } \\
\text { TSSCs }\end{array}$ & $\begin{array}{c}\text { Estimated } \\
\text { annual } \\
\text { complication } \\
\text { rates } \\
(95 \% C I)\end{array}$ & $\begin{array}{c}\text { Cumulative } \\
3 \text { year- } \\
\text { complication } \\
\text { rates } \\
(95 \% C I)\end{array}$ & $\begin{array}{c}\text { Number } \\
\text { of } \\
\text { TSSCs }\end{array}$ & $\begin{array}{c}\text { Estimated } \\
\text { annual } \\
\text { complication } \\
\text { rates } \\
(95 \% C I)\end{array}$ & $\begin{array}{c}\text { Cumulative } \\
3 \text { year- } \\
\text { complication } \\
\text { rates } \\
(95 \% C I)\end{array}$ & $\begin{array}{c}\text { Number } \\
\text { of } \\
\text { TSSCs }\end{array}$ & $\begin{array}{c}\text { Estimated } \\
\text { annual } \\
\text { complication } \\
\text { rates } \\
(95 \% C I)\end{array}$ & $\begin{array}{c}\text { Cumulative } \\
3 \text { year- } \\
\text { complication } \\
\text { rates } \\
(95 \% C I)\end{array}$ \\
\hline & \multicolumn{3}{|c|}{$\begin{array}{l}\text { Metal-ceramic SCs } \\
215 \text { TSSCs }\end{array}$} & \multicolumn{3}{|c|}{$\begin{array}{l}\text { Lithium disilicate glass ceramic SCs } \\
\text { 87 TSSCs }\end{array}$} & \multicolumn{3}{|c|}{$\begin{array}{l}\text { Zirconia Oxide ceramic SCs } \\
\text { 414 TSSCs }\end{array}$} \\
\hline $\begin{array}{l}\text { Non optimal } \\
\text { margin }\end{array}$ & 0 & 0 & $0 \%$ & 1 & $\begin{array}{c}0.01 \\
(0.009-0.029)\end{array}$ & $0 \%$ & 0 & 0 & $0 \%$ \\
\hline $\begin{array}{l}\text { Minor } \\
\text { chipping }\end{array}$ & 2 & $\begin{array}{c}0.009 \\
(0-0.028)\end{array}$ & $\begin{array}{c}0.88 \% \\
(0-2.69 \%)\end{array}$ & 11 & $\begin{array}{c}0.12 \\
(0.082-0.158)\end{array}$ & $0 \%$ & 4 & $\begin{array}{c}0.009 \\
(0-0.049)\end{array}$ & $\begin{array}{c}0.68 \% \\
(0-1.6 \%)\end{array}$ \\
\hline $\begin{array}{l}\text { Major } \\
\text { chipping }\end{array}$ & 2 & $\begin{array}{c}0.009 \\
(0-0.028)\end{array}$ & $\begin{array}{c}0.44 \% \\
(0-1.34 \%)\end{array}$ & 4 & $\begin{array}{c}0.043 \\
(0.04-0.045)\end{array}$ & $\begin{array}{c}2.18 \% \\
(1.7-5.5 \%)\end{array}$ & 1 & $\begin{array}{c}0.002 \\
(0-0.011)\end{array}$ & $\begin{array}{c}0.23 \% \\
(0-1.08 \%)\end{array}$ \\
\hline $\begin{array}{l}\text { Crown } \\
\text { fracture }\end{array}$ & 2 & $\begin{array}{c}0.009 \\
(0-0.028)\end{array}$ & $\begin{array}{c}0.44 \% \\
(0-1.34 \%)\end{array}$ & 1 & $\begin{array}{c}0.01 \\
(0.009-0.029)\end{array}$ & $\begin{array}{c}1.09 \% \\
(0.85-2.75 \%)\end{array}$ & 3 & $\begin{array}{c}0.007 \\
(0-0.028)\end{array}$ & $\begin{array}{c}0.68 \% \\
(0-1.6 \%)\end{array}$ \\
\hline Post fracture & 0 & 0 & $0 \%$ & 1 & $\begin{array}{c}0.01 \\
(0.009-0.029)\end{array}$ & $0 \%$ & 0 & 0 & $0 \%$ \\
\hline $\begin{array}{l}\text { Loss of } \\
\text { retention }\end{array}$ & 0 & 0 & $0 \%$ & 6 & $\begin{array}{c}0.065 \\
(0.055-0.074)\end{array}$ & $0 \%$ & 3 & $\begin{array}{c}0.007 \\
(0-0.028)\end{array}$ & $\begin{array}{c}0.23 \% \\
(0-1.08 \%)\end{array}$ \\
\hline $\begin{array}{l}\text { Anatomic } \\
\text { form/ Contact } \\
\text { point/ Food } \\
\text { impact }\end{array}$ & 0 & 0 & $0 \%$ & 0 & 0 & $0 \%$ & 152 & $\begin{array}{c}0.35 \\
(0.19-0.5)\end{array}$ & $\begin{array}{l}34.87 \% \\
(19.03-\end{array}$ \\
\hline $\begin{array}{l}\text { Marginal } \\
\text { discrepancy }\end{array}$ & 0 & 0 & $0 \%$ & 1 & $\begin{array}{c}0.01 \\
(0.009-0.029)\end{array}$ & $\begin{array}{c}1.9 \% \\
(0.85-2.75 \%)\end{array}$ & 0 & 0 & $\begin{array}{c}50.73 \%) \\
0 \%\end{array}$ \\
\hline $\begin{array}{l}\text { Charlie + } \\
\text { Bravo [Tab } \\
\text { III] }\end{array}$ & 3 & $\begin{array}{c}0.013 \\
(0.004-0.031)\end{array}$ & $\begin{array}{c}0.88 \% \\
(0-2.69 \%)\end{array}$ & 0 & 0 & $0 \%$ & 14 & $\begin{array}{c}0.032 \\
(0.024-0.04)\end{array}$ & $\begin{array}{c}2.52 \% \\
(1.35- \\
3.69 \%)\end{array}$ \\
\hline
\end{tabular}

\section{Technical complications}

Non optimal margin, marginal discrepancy, minor and major chipping, crown fracture, post fracture, loss of retention, anatomical form and "the coping fracture, the veneering fracture the occlusal wear, the marginal adaptation and the anatomical form" according to the USPHS criteria and described as Bravo (B).

The solutions adopted for the different technical complications were:

- A clinical check-up for the non-marginal adaptation was adopted as a solution for a one case reported as an all-ceramic SC made out of Lithium during a mean follow-up time of 11.4 +/- 3.8 years in one study, no clinical or technical intervention was need [6].

- The minor chipping was the most common complication reported and the polishing of ceramic was the solution to adopt for 2 metal-ceramic single crowns reported in one study, 11 single crown made out of Lithium and 4 single crowns made out of Zirconium [6, 7, 10].
- The loss of retention were reported for 9 all-ceramic crowns in two studies; 4 crowns had been luted adhesively and 2 had been cemented conventionally for the 3 crowns reported in the second study the technique of cementation was not mentioned $[6,7]$.

- The unsatisfying anatomical form and contact point was reported on 152 all-ceramic single crown made out of Zirconium and zirconia-oxide in on study, no intervention was need, only a clinical follow-up was planned based on crown check-up and hygiene motivation [11].

- The Bravo criterion reported on the minor chipping, the occlusal wear, the slight probe catch and the slightly contoured according to the USPHS criteria; was considered as technical complication affected one metal-ceramic single crown and 7 allceramic single crowns made out of zirconium with the Lava and Procera systems in one study [9]. The polishing and the clinical control were the solutions to adopt.

The major chipping, the crown fracture, the post fracture and the marginal discrepancy were reported as failure and the crown replacement was need. 
Table 6: Overview of biological complications for different types of SCs.

\begin{tabular}{|c|c|c|c|c|c|c|c|c|c|}
\hline Complication & $\begin{array}{c}\text { Number } \\
\text { of } \\
\text { TSSCs }\end{array}$ & $\begin{array}{c}\text { Estimated } \\
\text { annual } \\
\text { complication } \\
\text { rates } \\
(95 \% C I)\end{array}$ & $\begin{array}{c}\text { Cumulative } \\
3 \text { year- } \\
\text { complication } \\
\text { rates } \\
(95 \% C I)\end{array}$ & $\begin{array}{c}\text { Number } \\
\text { of } \\
\text { TSSCs }\end{array}$ & $\begin{array}{c}\text { Estimated } \\
\text { annual } \\
\text { complication } \\
\text { rates }(95 \% C I)\end{array}$ & $\begin{array}{c}\text { Cumulative } \\
3 \text { year- } \\
\text { complication } \\
\text { rates } \\
(95 \% C I)\end{array}$ & $\begin{array}{c}\text { Number } \\
\text { of } \\
\text { TSSCs }\end{array}$ & $\begin{array}{c}\text { Estimated } \\
\text { annual } \\
\text { complication } \\
\text { rates } \\
(95 \% C I)\end{array}$ & $\begin{array}{c}\text { Cumulative } \\
3 \text { year- } \\
\text { complication } \\
\text { rates }(95 \% C I)\end{array}$ \\
\hline \multirow[b]{2}{*}{$\begin{array}{l}\text { Endodontic } \\
\text { diseases }\end{array}$} & \multicolumn{3}{|c|}{$\begin{array}{l}\text { Metal-ceramic SCs } \\
215 \text { TSSCs }\end{array}$} & \multicolumn{3}{|c|}{$\begin{array}{l}\text { Lithium disilicate glass ceramic SCs } \\
\qquad 87 \text { TSSCs }\end{array}$} & \multicolumn{3}{|c|}{$\begin{array}{l}\text { Zirconia Oxide ceramic SCs } \\
\qquad 414 \text { TSSCs }\end{array}$} \\
\hline & 6 & $\begin{array}{c}0.026 \\
(0.015- \\
0.037)\end{array}$ & $\begin{array}{c}2.2 \% \\
(0.99- \\
3.42 \%)\end{array}$ & 6 & $\begin{array}{c}0.065 \\
(0.046-0.083)\end{array}$ & $0 \%$ & 2 & $\begin{array}{c}0.004 \\
(0-0.023)\end{array}$ & $\begin{array}{c}0.46 \% \\
(0-2.17 \%)\end{array}$ \\
\hline $\begin{array}{l}\text { Periodontal } \\
\text { diseases }\end{array}$ & 4 & $\begin{array}{c}0.017 \\
(0.001- \\
0.033)\end{array}$ & $\begin{array}{c}0.85 \% \\
(0-1.09 \%)\end{array}$ & 9 & $\begin{array}{c}0.098 \\
(0.07-0.12)\end{array}$ & $\begin{array}{c}1.09 \% \\
(0.85- \\
2.75 \%)\end{array}$ & 49 & $\begin{array}{c}0.11 \\
(0.077-0.14)\end{array}$ & $\begin{array}{c}11.24 \% \\
(7.71-14.76 \%)\end{array}$ \\
\hline $\begin{array}{l}\text { Adjacent } \\
\text { mucosa }\end{array}$ & 0 & 0 & $0 \%$ & 1 & $\begin{array}{c}0.01 \\
(0.009-0.029)\end{array}$ & $\begin{array}{c}1.09 \% \\
(0.85- \\
2.75 \%)\end{array}$ & 40 & $\begin{array}{c}0.092 \\
(0.068-0.11)\end{array}$ & $\begin{array}{c}9.17 \% \\
(6.73-11.62 \%)\end{array}$ \\
\hline $\begin{array}{l}\text { Root-treatment } \\
\text { for crown } \\
\text { laying }\end{array}$ & 14 & $\begin{array}{c}0.062 \\
(0.054- \\
0.069)\end{array}$ & $\begin{array}{c}6.18 \% \\
(5.13- \\
6.55 \%)\end{array}$ & 0 & 0 & $0 \%$ & 9 & $\begin{array}{c}0.02 \\
(0.005-0.034)\end{array}$ & $\begin{array}{c}2.06 \% \\
(0.55-3.44 \%)\end{array}$ \\
\hline Caries & 2 & $\begin{array}{c}0.009 \\
(0-0.028)\end{array}$ & $\begin{array}{c}0.88 \% \\
(0-2.69 \%)\end{array}$ & 3 & $\begin{array}{c}0.033 \\
(0.025-0.04)\end{array}$ & $0 \%$ & 6 & $\begin{array}{c}0.013 \\
(0.003-0.032)\end{array}$ & $\begin{array}{c}0.92 \% \\
(0-2.8 \%)\end{array}$ \\
\hline Tooth-fracture & 0 & 0 & $0 \%$ & 2 & $\begin{array}{c}0.021 \\
(0.008-0.035)\end{array}$ & $\begin{array}{c}1.09 \% \\
(0.85- \\
2.75 \%)\end{array}$ & 0 & 0 & $0 \%$ \\
\hline
\end{tabular}

Charlie and Delta criterion according to the USPHS criteria were reported as failure and the loss of crown was a fact [9].

- 7 crowns were lost by major chipping; 4 crowns made out of Lithium, one crown made out of zirconium and 2 metal-ceramic SCs $[6,8,10]$.

- The crown fracture was reported in two studies and affected one all-ceramic crown made out of Lithium and 2 metal-ceramic SCs $[6,8]$.

- The crown replacement by marginal discrepancy was reported on one crown made out of Lithium as well as the post fracture [6].

- For Charlie and Delta according to USPHP criteria; 9 crowns were lost in which 2 metal-ceramic crowns and 7 all-ceramic crowns made out of Zirconium [9].

According to table 5; the ceramic chipping was a common problem, and overall occurred similarly at the metal-ceramics and the all-ceramic crowns. Furthermore, for metal ceramic crowns, minor chipping was the most frequent technical complication with a cumulative 3 -years event rate of $0.88 \%$ (95\% CI: 0-2.69). For all-ceramic a tendency to major chipping of the veneering ceramic was more observed for Lithium than the zirconia oxide
( $2.18 \%$ VS $0.23 \%$ ), opposite to minor chipping with $0.68 \%$ cumulative 3-year event rate for Zirconium crowns VS 0\% for the Lithium ones (Table 5).

Crown fracture rarely occurred for metal-ceramic crowns (cumulative 3-year complication rate 0.44\%; 95\% CI: 0-1.34\%). Overall, this problem occurred significantly more often for ceramic crowns. The Lithium glass ceramic exhibited the highest 3 -year crown fracture rate of $1.09 \%$ (95\% CI: $0.85-2.75 \%$ ) when the Zirconia-based single crowns showed only $0.68 \%$ as an event rate. (95\% CI: 0-1.6\%). With the exception of zirconiabased crowns, loss of retention was not a predominant technical problem. Only crowns made out of zirconium exhibited loss of retention during a 3 years follow up time (estimated 3-year complication rate $0.23 \%$; CI: $0-1.08 \%$ ).

Only zirconia TSSCs exhibit an unsatisfying anatomic form as a technical complication with a 3-years event rate of $34.87 \%$ (95\% CI: 19.03-50.73\%) (Table 6).

\section{All-ceramic VS metal-ceramic technical complications}

According to table 7; ceramic chipping affected much more the metal-ceramic crowns than the all-ceramic crowns with a cumulative 3 -years complication rate of $0.88 \%$ VS $0.56 \%$ 
All-Ceramic versus Metal-Ceramic Tooth Supported Single Crowns with a Minimum Follow-up Time of 3 Years; Survival and Complications: A Systematic

Table 7: Overview of technical and biological complications for metal-ceramic versus all-ceramic TSSCs.

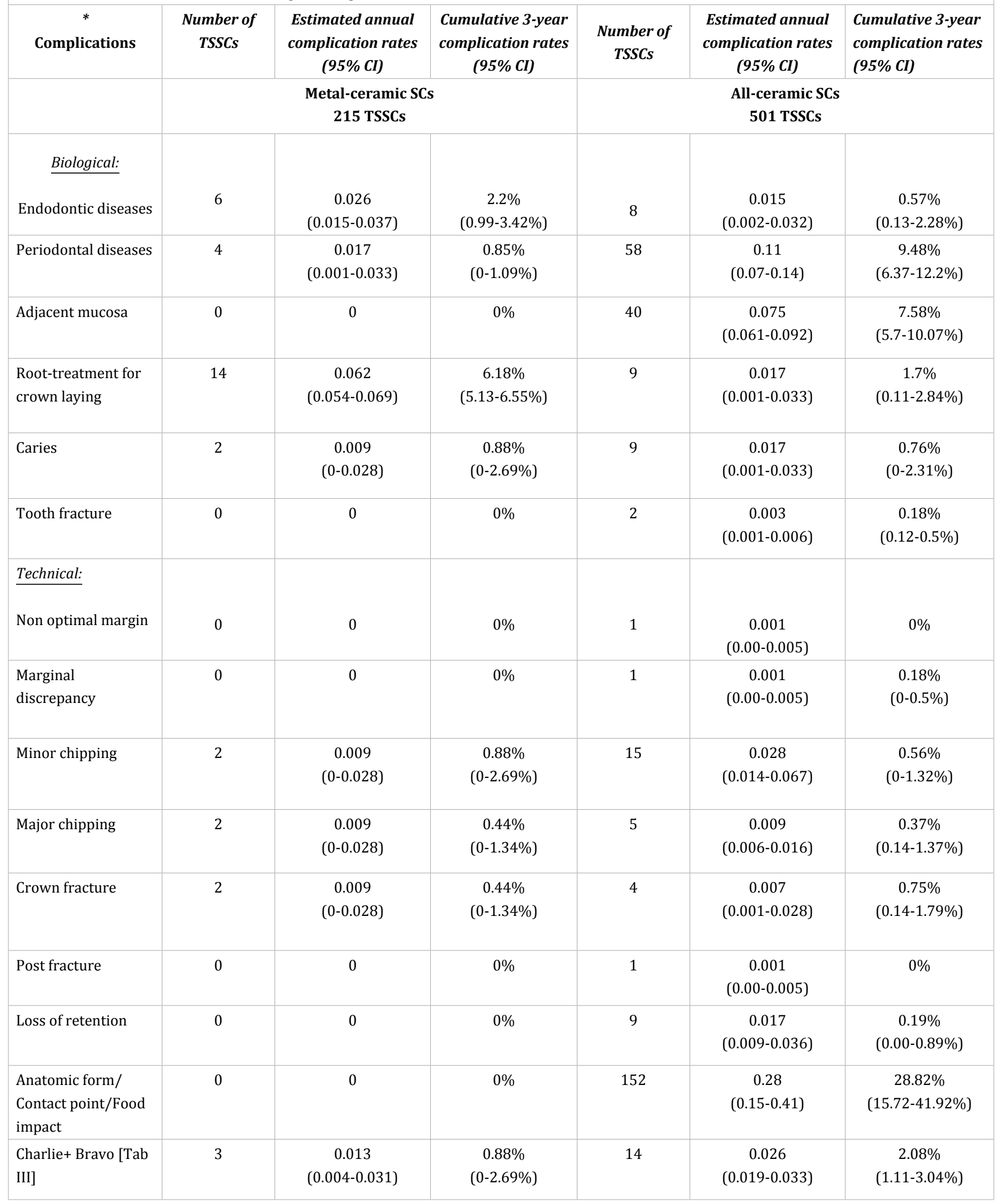

Citation: D. Hadyaoui, Imen k, Ayda L, Mounir C, et al. (2018) All-Ceramic versus Metal-Ceramic Tooth Supported Single Crowns with Page 11 of 14 a Minimum Follow-up Time of 3 Years; Survival and Complications: A Systematic Literature Review. J Dent Oral Disord Ther 6(1): 1-14. 
for minor chipping and $0.44 \%$ VS $0.37 \%$ for major chipping. For crown fracture the all-ceramic crowns exhibit a superior cumulative 3-years complication rate compared to metal-ceramic crowns $(0.75 \%$ VS $0.44 \%)$.

The loss of retention, the marginal discrepancy and the clinically controlled not-satisfying form and contact point affected only the all-ceramic crowns with a cumulative 3-years complication rate of $0.19 \%$ (95\%; CI: $0.00-0.89 \%$ ), $0.18 \%$ (95\%; CI: $0.00-0.5 \%$ ) and $28.82 \%$ (95\%; CI: $15.72-41.92 \%$ ) respectively.

For the USPHS [Tab 3], the criterions Bravo, Charlie and Delta were considered as technical complications that leaded to clinical control, intervention and loss of the crown respectively and they occurred significantly more often for all-ceramic crowns than metal-ceramic ones (2.08\% VS 0.88\%). During the 3-years follow-up time, metal-ceramic TSSCs a superior rate of SCs free of technical complication in comparison with the all-ceramic ones. (92.36\% VS 62.05\%) (Table 7).

\section{Biological complications}

Loss of abutment tooth vitality, abutment tooth fracture, endodontic and periodontal infections, recurrent caries lesions, lesion of the adjacent mucosa and extraction due to infection (caries, periodontal or endodontic infections), were reported as biological complications for TSSCs.

The solutions adopted for different biological complications were:

Root treatment for crown laying in 14 posterior metal-ceramic TSSCs and 9 posterior all-ceramic TSSCs made out of zirconium [10]. 5 TSSCs were canal treated for endodontic infection; 2 anterior TSSCs made out of Lithium, one metal-ceramic TSSC and 2 all-ceramic TSSCs made out of zirconium $[6,10]$. A periodontal treatment was adopted for the several periodontal infections and diseases on 3 posterior Lithium TSSCs and 48 posterior Zirconia TSSCs $[6,11]$.

Only one case was reported for recurrent caries treatment on one TSSCs made out of zirconium [7]. The lesion of the adjacent mucosa was clinically controlled on 40 posterior Zirconia TSSCs [11]. The tooth fracture and the extraction due to infection (recurrent caries, periodontal and endodontic diseases) were reported as failures, during the different studies. Two anterior abutment teeth were lost by fracture with crowns made out of lithium [6]. 28 TSSCs were extracted due to infections (periodontal and endodontic diseases and recurrent caries). 13 lithium TSSCs [6], 4 Zirconia TSSCs and 11 metal-ceramic TSSCs. [7, 8, 10].

According to Table 6; the periodontal diseases were common biological complication and the most frequent for Zirconia TSSCs (3-year complication rate 11.24\%; 95\% CI: 7.71-14.76\%). This problem less frequently occurred for lithium and metalceramic TSSCs with 3-year complication rate of $1.09 \%$ and $0.85 \%$ respectively. In addition, the marginal discrepancy and the lesion of the adjacent mucosa were also predominantly found for Zirconia TSSCs (3-year complication rate 9.17\%; 95\% CI: 6.73-
$11.62 \%)$. This complication occurred significantly less frequently for Lithium with 3-year complication rate of 1.09\% (CI: 0.85$2.75 \%$ ) and not existing for metal-ceramic TSSCs.

Furthermore, the endodontic diseases were a common biological problem for the different types of TSSCs, with a cumulative 3-years complication rates for Metal-ceramic, Lithium and Zirconia of $2.2 \%, 1.09 \%$ and $0.46 \%$ respectively. The loss of vitality by root-canal-treatment for prosthodontic reasons affected only the Zirconia and the metal-ceramic TSSCs and showed a cumulative 3-years complication rates of $2.06 \%$ and $6.18 \%$ respectively. Finally, tooth fracture affected only the Lithium TSSCs with a cumulative 3-years complication rate of $1.09 \%$; CI: $0.85-2.75 \%$, when the caries affected the TSSCs made out of metal-ceramic and Zirconia with cumulative 3-years complication rates of $0.88 \%$ and $0.92 \%$ respectively.

\section{All-ceramic VS metal-ceramic biological complications}

According to table 7; endodontic and periodontal diseases, caries and loss of tooth vitality for prosthodontic reasons were the most common biological complications for all-ceramic and metal-ceramic TSSCs. Periodontal diseases occurred significantly high frequently for all-ceramics with a cumulative 3-years complication rate of $9.48 \%$ (95\%; CI: $6.37-12.2 \%$ ), when metalceramic TSSCs showed only a cumulative 3-years complication rate of $0.85 \%$ (95\%; CI: 0-1.09\%). For marginal discrepancy and the affection of adjacent mucosa, only all-ceramic crowns showed the unfolding of this event with a cumulative 3-year complication rate of $7.77 \%$ (95\%; CI: 5.7-10.08\%).

Endodontic diseases affected both metal-ceramic and all-ceramic TSSCs, with a 3-year complication rate of $0.85 \%$ VS $9.48 \%$, respectively. The loss of abutment tooth vitality for prosthodontic reasons, was also a common problem, but significantly occurred on metal-ceramic TSSCs compared to the all-ceramic ones (6.18\% VS 1.7\%). Recurrent caries were a rare event, but affected both metal-ceramic and all-ceramic TSSCs with a 3-year cumulative complication rate of $0.88 \%$ VS $0.76 \%$, respectively. The tooth fracture happened only on all-ceramic TSSCs with a 3-year cumulative complication rate of $0.18 \%$. Metal-ceramic TSSCs showed a 3-years free-biological event rate of $84.89 \%$, when all-ceramic TSSCs showed only $74.73 \%$.

\section{Discussion}

This systematic review focused on the results of prospective clinical studies and case series that would compare head-to-head the different core materials of TSSCs along with a randomized controlled trial $[9,10]$. Retrospective and in vitro studies, narrative review, case and clinical reports and studies with a mean follow-up period less than 3 years were excluded to summarize the available information about survival and complication rates of TSSCs after a period of at least 3 years. Even with follow-up time of at least 3 years, some clinicians may argue that such a period is still too short to obtain reliable information on survival and complication rates $[12,13]$. 
After an observation period of 3 years, the lowest annual failure rates were seen for Zirconia TSSCs $(0.031$ per 100 SCs years). Multivariable random-effect Poisson's regression showed that Lithium TSSCs had significantly higher annual failure rates of about 0.057 per 100 SCs years. Furthermore, the analyzing study reporting on lithium TSSCs [6] with a mean follow-up time of 11.4 +/- 3.8 years had expressed an annual failure rate about 0.195 per 100 SCs years, translating into 10 -year survival rate of $89.7 \%$. This highest statistically significant failure rate of TSSCs may have his origin from the limited indication of the Lithium disilicate at the posterior regions. This study evoked the potential updating indication of such core material at the posterior regions. But it is still always limited especially for molars because of the high fracture rates.

For Gianluca M. et al., 2015 reporting on zirconia TSSCs with 7-years mean follow-up time, a failure rate of 0.054 per 100 SCs years had been reported [7]. When Mutinelli S. et al., 2012 had reported an annual failure rate of 0.105 for CC TSSCs made by the Lava system, while the Procera ones had a failure rate of 0.201 for a 5-years mean follow-up time [9]. This difference may have cause from the several types of manufacturing procedures. One study reported on zirconia TSSCs with a failure rate of 0.015 by 3 years, this statistical expressed difference amounts to both the observation period and the laying sites (posterior and anterior regions).

The choice of zirconia as a core material for SCs, both in posterior and anterior sites, has been increasing over time with clinical results that seem quite comparable to the gold standard MC TSS restorations, although clinical trials are very few, to date specially on TSSCs. Zirconia SCs showed a success rate of $93 \%$ after a 2 years observation period, with a favorable soft tissue response, in a limited sample size of 15 Cercon crowns (Dentsply Degudent, Hanau, Germany). Another investigation with a longer observational period (3 years), performed on 204 Procera zirconia SCs delivered in a private practice, showed a survival rate of $93 \%$; in this study, $16 \%$ of complication were recorded (6\% loss of retention, $2.5 \%$ extraction of abutment teeth, $5 \%$ persistent pain, $2 \%$ porcelain chipping) [14].

For the MC gold standard, a clinical observation of 10 years mean follow-up time [8] had expressed a failure rate of 0.054 per 100 crowns which remain the same during the first 3 years of this study. For another one with a 5-years mean follow-up time; TSSCs had a failure rate of 0.1 per 100 crown which had been expressed lower in the first 3 -years of observation $(0.05$ per 100 crown)[9]. This result was caused by the occurrence of biological complications.

MC TSSCs had expressed a highest annual failure rate compared to the zirconia ones ( 0.051 VS 0.031 per 100 crown), this is due to the occurrence of biological complications such as recurrent caries, periodontal and endodontic diseases and specially the lost of the abutment tooth vitality. Even if we cannot ignore that Zirconia SCs had expressed much more biological complications specially periodontal diseases in population of
414 TSSCs analyzed during this study, this can only be the fact of the precision of fit for a such material which depends on various factors, like; differences in manufacturing systems, individual characteristics of the SCs (regions), core-porcelain ratio, framework architecture, effect of veneering and influence of aging in same reported cases. As to soft-machined 3Y-TZP restorations, the precise numerical compensation required by such a system of the enlargement ratio of the model is a paramount factor, strictly dependent also on the composition and homogeneity of presintered zirconia blanks that should be consistent and precise [15].

Overall the lithium TSSCs had expressed a closer failure rate to the MC ones. But it is still higher compared to the gold standard SCs (0.057 VS 0.051). This may due to the occurrence of technical complications on Lithium TSSCs in anterior regions. Technically, ceramic chipping, crown fracture and unsatisfactory anatomic form were the main complication of the all-ceramics. This problem was most specifically found when weaker ceramic materials were used [6]. The same observation was made when the outcomes of the SCs in anterior and posterior regions were compared. Metal-ceramic SCs performed a higher failure rate comparing to lithium SCs when it comes to the posterior regions (0.051 VS 0.04) whereas the Zirconia ones had the lowest annual failure rate $(0.035$ per 100 crown). For the anterior regions we can only compare the CC TSSCs, as the MC ones were all laid in the posterior regions.

Biologically, all-ceramic TSSCs seemed to perform better than the gold standard, MC SCs. Significantly more loss of abutment tooth vitality and endodontic diseases was reported for MC TSSCs. While periodontal affections and tooth fracture, were more expressed on CC TSSCs especially to the Zirconia ones. This is caused by the unsatisfactory anatomic form of the last mentioned type of SCs. In the present review, 3 studies on posterior MC TSSCs were available as well as a few number of studies evaluating all-ceramic TSSCs. [6-11]. The results of the present review, hence, may be considered more robust with more impact of the daily practice and on pending further studies.

In present review, it was shown that all-ceramic crowns made out of Lithium can be recommended as an alternative treatment option to the MCs for TSSCs in anterior and posterior regions [6]. But still less stable in the posterior sites, so they are remaining until now, for anterior indication. Hansel K. et al., had evoked another factor that may affect the choice of the core material which is Bruxism. MC TSSCs showed good longevity on vital posterior teeth especially in the case of Bruxism. This may due to the amortization properties of the gold standard SCs [8].

\section{Conclusion}

The review also indicated that zirconia based SCs performed less well in clinics, despite the enhanced mechanical stability of this oxide ceramic. Failure due to extensive fracture of the veneering ceramic, loss of retention and non-satisfying anatomic form were found as technical problems for this type of ceramic crowns. The more recent clinical studies showed that despite all 
developments and efforts for the improvement of the veneering procedures of zirconia and lithium frameworks, the problem of chipping ceramic has not been eliminated yet $[12,13,15,16]$. The trend toward an increasingly extended use of all-ceramic SCs is an undeniable reality in FDPs. After the development era, dental ceramics introduced in the last 20 years exhibit different, favorable and promising esthetic and mechanical properties. At the moment, there is no one ceramic material that equally excels in all these characteristics.

The choice of one specific typology of ceramic, rather than the latest fashion, should be based on a careful evaluation of the very advantages and disadvantages of the material related to the specific dental application [15]. Consequently, all-ceramic TSSCs should not be considered as the primary treatment option for now, and patients need to be thoroughly informed about current limitations. Another factor influencing the choice of the material for TSSCs in daily clinical practice is the biological outcome of the reconstructions.

According to Surabh Gupta, "The use of zirconium became widespread because it's very hars and strongand is also usedto make bridges and crowns" [16].

\section{Reference}

1. Agency for Drugs and Technologies in Health. All-Ceramic Crowns Compared to Porcelain-Fused-to-Metal Crowns in Adults: Review of Long Term Clinical Effectiveness and Cost-Effectiveness. CADTH Evidence Driven.2013:RC0487-000

2. Hämmerle $\mathrm{CH}$, Pjetursson BE, Sailer I and Zwahlen M. A systematic review of the survival and complication rates of allceramic and metal-ceramic reconstructions after an observation period of at least 3 years. Part I: Single crowns. Clin Oral Implants Res. 2007;18(S3):73-85.

3. Hämmerle $\mathrm{CH}$, Pjetursson BE, Sailer I and Zwahlen M. A systematic review of the survival and complication rates of allceramic and metal-ceramic reconstructions after an observation period of at least 3 years. Part II: Fixed dental prostheses. Clin Oral Implants Res. 2007;18(S3):86-96.

4. Kirkwood BR and Sterne JAC. Essential Medical Statistics. Fiona Goodgame and Karen Moore editors. Chapter 24: Poisson Regression. Oxford: Blackwell Science Ltd;2003:249-262.

5. Kirkwood BR and Sterne JAC. Essential Medical Statistics. Fiona Goodgame and Karen Moore editors. Chapter 26: Survival Analysis: Displaying and Comparing Survival Patterns. Oxford: Blackwell Science Ltd;2003:272-286.
6. Edelhoffd D, Göcklera F, Teichmanna M, Weberb V, Wolfarta S, and Yildirimc M. Ten-year survival and complication rates of lithium-disilicate (Empress 2) tooth-supported crowns, implant-supported crowns, and fixed dental prostheses J Dent. 2017;56:65-77. doi: 10.1016/j.jdent.2016.10.017.

7. Gianluca M. Tartaglia, Sforza C and Sidoti E. Seven-year prospective clinical study on zirconia-based single crowns and fixed dental prostheses. Clin Oral Investig. 2015;19(5):1137-1145. doi: 10.1007/s00784-014-1330-2.

8. Hansel K, Kastner C, Reitemeier B, Weber A and Walter MH. A prospective 10-year study of metal ceramic single crowns and fixed dental prosthesis retainers in private practice settings. J Prosthet Dent. 2013;109(3):149155. doi: 10.1016/S0022-3913(13)60034-7

9. Mutinelli $S$ and Vigolo P. Evaluation of Zirconium-Oxide-Based Ceramic Single-Unit Posterior Fixed Dental Prostheses (FDPs) Generated with Two CAD/CAM Systems Compared to Porcelain-Fused-toMetal Single-Unit Posterior FDPs: A 5-Year Clinical Prospective Study. J Prosthodont. 2012;21(4):265-269. doi: 10.1111/j.1532849X.2011.00825.x.

10. Gersdorff N, Lange K, Rinke S, Roediger M and Schäfer S. Practice-based clinical evaluation of metal-ceramic and zirconia molar crowns: 3-year results. J Oral Rehabil. 2013;40(3):228-37. doi: 10.1111/joor.12018.

11. Sforza C, Sidoti E and Tartaglia GM. A 3-year follow-up study of all-ceramic single and multiple crowns performed in a private practice: a prospective case series. Clinics (Sao Paulo).2011;66(12):2063-2070.

12. Brägger U, Pjetursson BE, Lang NP and Zwahlen M. Comparison of survival and complication rates of tooth-supported fixeddental prostheses (FDPs) and implantsupported FDPs and single crowns (SCs). Clin Oral Implants Res. 2007;18 (S3):97-113.

13. Makarov NA, Pjetursson BE, Sailer I, Thoma DS and Zwahlen M. Corrigendum to "All-ceramic or metal-ceramic tooth- supported fixed dental prostheses (FDPs)? A systematic review of the survival and complication rates. Part I: Single crowns (SCs)". Dental Materials. 2015;31(6):603-623.

14. Poulsen S Dr Odont. Epidemiology and indices of gingival and periodontal diseases. Journal of Pediatric dentistry by the American Academy of Pedodontics. 1981;3:82-88.

15. Russo S, Sorrentino R and Zarone F. From porcelain-fused-to-metal to zirconia: clinical and experimental considerations. Dent Mater. 2011;27(1):83-96.

16. Canadian Agency for Drugs and Technologies in Health. All-Ceramic Crowns Compared to Porcelain-Fused-to-Metal Crowns in Adults: Review of Long Term Clinical Effectiveness and Cost-Effectiveness. CADTH Evidence Driven.2013:RC0487-000.

17. Surabh Gupta. Zirconia vs Titanuim implants-Deciding factors. J Dent Oral Disord Ther. J Dent Oral Disord Ther.2016;4(4):1-2 . DOI: http://dx.doi.org/10.15226/jdodt.2016.00166 